Productivity in Health Services Conference Proceedings. Norcross, GA: Institute of Industrial Engineers; 1996:143-150.

110. Benneyan JC. On the Application and Interpretation of Control Charts With Unequal Subgroup Sizes With Application to Hospital Length of Stay Data. Technical Report. University of Massachusetts: Industrial Engineering and Operations Research; 1996.

111. Zimmerman SM, Brown LD, Brown SS, Alexander L. Human body function control charts for the physician. ASQC Quality Congress Transactions 1990:408-412.

112. Garlock JH, Seley GP. The use of sulfanilamide in surgery on the colon and rectum. preliminary report. Surgery 1939;5:787-790.

113. Classen DC, Evans RS, Pestotnik SL, Horn SD, Menlove RL, Burke JP. The timing of prophylactic administration of antibiotics and the risk of surgical-wound infection. N Engl J Med 1992;326:281-286.

114. Wenzel RP. Preoperative prophylactic antibiotics: brief historical note. Infect Control Hosp Epidemiol 1993;14:121.

115. Jackson JE. All count distributions are not alike. Journal of Quality Technology 1972;4(2):86-92.

116. Johnson NL, Kotz S, Kemp AW. Univariate Discrete Distributions. 2nd ed. New York, NY: John Wiley and Sons, Inc; 1992.

117. Mendenhall W, Scheaffer RL, Wackerly DD. Mathematical Statistical with Applications. 4th ed. Boston, MA: Duxbury Press; 1990.

118. Devore JL. Probability and Statistics for Engineering and the Sciences. 2nd ed. Monterey, CA: Brooks/Cole Publishing Co; 1987.

119. Guttman I, Wilks SS, Hunter JS. Introductory Engineering Statistics. 3rd ed. New York, NY: John Wiley and Sons, Inc; 1982.

120. Benneyan JC. Statistical Control Charts Based on Geometric and Negative Binomial Distributions. University of Massachusetts, Amherst, MA; 1992. Thesis.

121. Kaminsky FC, Benneyan JC, Davis RB, Burke RJ. Statistical contro charts based on a geometric distribution. Journal of Quality Technology 1992;24(2):63-69.

122. Newell DJ. Unusual frequency distributions. Biometrics 1965;21:159168.

123. Brawley RL, Weber DJ, Samsa GP, Rutala WA. Multiple nosocomial infections, an incidence study. Am J Epidemiol 1989;130:769-780.
124. Benneyan JC An introduction to using statistical process control (SPC) within health care. International Applied Statistics in Medicine Conference Transactions. In press.

125. Benneyan JC, Kaminsky FC. Successfully applying SPC to improve health care: pitfalls and barriers to improving quality and reducing liability. Proceedings of the ASQC Annual Quality Congress Transactions. Milwaukee, WI: American Society for Quality, Inc; 1995:578-586.

126. Liu MC, Fernandez JE, Davis PJ. A statistical process control approach to carpal tunnel syndrome risk evaluation. Quality Engineering 1993;5:375-392.

127. Alemi F, Rom W, Eisenstein E. Risk adjusted control charts for healthcare assessment. Annals of Operations Research 1996;67:45-60.

128. Sloan MD, ed. Success Stories on Lowering Health Care Costs by Improving Health Care Quality. Milwaukee, WI: ASQC Press; 1995.

129. Wernimont G. Use of control charts in the analytic laboratory. Ind Eng Chem Anal Ed 1946;18:587-592.

130. Levey S, Jennings ER. The use of control charts in clinical laboratories. Am J Clin Pathol 1950;20:1059-1066.

131. Benneyan JC. Statistical Quality Control in Clinical Laboratories. Technical Report. University of Massachusetts: Industrial Engineering and Operations Research; 1995.

132. Kaminsky FC, Benneyan JC, Andrzewski C. Total Quality Management and Statistical Process Control in the Clinical Laboratory With Applications to EIA Testing for HIV-1/2 and Hepatitis Antibodies. Technical Report. Greenfield, MA: Productivity Sciences Inc; 1995

133. Gentleman RC, Hamada MS, Matthews DE, Wilson AR. Statistical quality control of HIV-1 ELISA test performance. Journal of the American Statistical Association 1994;89:1200-1208.

134. Carey RG. Measuring Quality: Report Cards Get Low Grades. Parkridge, IL: Parkside Associates; 1995.

135. O'Leary DS. Measurement and accountability: taking careful aim. It Comm Journal on Quality Improvement 1995;21:354-357.

\title{
Control of Legionella pneumophila in Hospital Hot-Water Supply
}

\section{Gina Pugliese, RN, MS Martin S. Favero, $\mathrm{PhD}$}

Heat treatment and application of copper-silver ionization often are used for controlling Legionella pneumophila in high-volume hospital plumbing systems. However, the comparative efficacies of these measures in high-volume systems are unknown.

Investigators from Children's Hospital of Pittsburgh have reported on studies that show differences in efficacy. Thermal treatment of a hotwater circuit was accomplished by flushing hot water $\left(>60^{\circ} \mathrm{C}\right)$ through distal fixtures for 10 minutes. Coppersilver ionization was conducted in three circuits by installing units into return lines immediately upstream from hot-water tanks. Recovery rates of $L$ pneumophila were monitored by culturing swab samples from faucets. Concentrations of copper and silver in water samples were determined by atomic absorption spectrophotometry. Four heat-flush treatments failed to provide long-term control of $L$ pneumophila. In contrast, ionization treatment reduced the rate of recovery of $L$ pneumophila from 108 faucets from $72 \%$ to $2 \%$ within 1 month and maintained effective control for at least 22 months. Only three samples $(1.9 \%)$ of hot water from faucets exceeded Environmental Protection Agency standards for silver, and none exceeded the standards for copper. Of 24 sam- ples obtained from hot-water tanks, $42 \%$ and $50 \%$ exceeded the silver and copper standards, respectively.

The authors concluded that copper-silver ionization effectively controls $L$ pneumophila in high-volume plumbing systems and is superior to thermal treatment. However, high concentrations of copper and silver can accumulate at the bottom of hotwater tanks.

From: Miuetzner S, Schwille RC, Farley A, Wald ER, Ge JH, States SJ. Efficacy of thermal treatment and copper-silver ionization for controlling Legionella pneumophila in highvolume hot water plumbing systems in hospitals. Am J Infect Control 1997;25:452-457. 